\title{
Erysiphe polygoni Induced Morpho-physiological and Biochemical Changes in Blackgram (Vigna mungo)
}

\author{
Tulasi Korra ${ }^{1}$ and V. Manoj Kumar ${ }^{2}$
}

${ }^{I}$ Department of Mycology and Plant Pathology, Banaras Hindu University, Varanasi, India

${ }^{2}$ Department of Plant Pathology, Acharya N. Ranga Agricultural University, Bapatla, LAM, Guntur, India

*Corresponding author

\section{A B S T R A C T}

\section{Keywords}

Black gram, Morphological and Biochemical and Erysiphe polygoni

Article Info

Accepted:

17 June 2020

Available Online:

10 July 2020
Morpho-physiological and biochemical changes was carried out for 16 germplasm lines of Urdbean against disease powdery mildew caused by Erysiphe polygoni, where KUP-34 recorded as significantly high in leaf thickness, phenol content, trichome density, and lowest in total sugars, stomatal size, reducing sugars and non-reducing sugars compared to highly susceptible genotype LBG-623.

\section{Introduction}

Black gram is essential seed crop and the best source of phosphoric acid in the pluses and is an significant dietary protein level (Duffus and Slaughter, 1980). It's seed has the highest protein level $(25 \mathrm{~g} / 100 \mathrm{~g})$ with other aminoacids and minerals such as potassium, calcium, iron, niacin, thamine and riboflavin. Urdbean is an mini-fertilizer factory, which rehabilitates soil fecundity by raising atmospheric nitrogen, generates an equivalent of ' $N$ ' of approximately $22 \mathrm{~kg}$ per hectare (Rachie and Roberts, 1974). Blackgram genesis from Central Asia and currently found in tropical and subtropical areas around Africa, Asia, and Madagascar (Arora et al., 1989). It was domesticated in the neighbouring regions of South Asia. Globally, the production of black gram from the main producer countries like India, Myanmar or Thailand amounts to around 8.5 million tonnes.

The cultivated in an area of $3.56 \mathrm{Mt}$ and 655 $\mathrm{kg} / \mathrm{ha}$ was such as a third important pluses crop in a India. (Department Of Farming and Co-Operation, The Government of India, 2018 ) in region of 5.44Mh, with output. 
The objective of the current research was to check the effect of powdery mildew on different physio-biochemical traits in resistant and susceptible pea genotypes.

The possibility of these traits viz., electrolyte leakage, reducing sugars, non-reducing sugars, total sugars and plant dry weight as selection criteria for powdery mildew resistance was also assessed.

\section{Materials and Methods}

The experiment was conducted during rabi 2015-16, Agricultural College Farm and Department of Plant Pathology, Agricultural College, Bapatla, Guntur District. Geographically the Agricultural College Farm, Bapatla is situated at an altitude of $5 \mathrm{~m}$ above the mean sea level and at $80^{\circ} 30^{\prime} \mathrm{E}$ Longitude and $15^{\circ} 54^{\prime} \mathrm{N}$ Latitude and seven $\mathrm{km}$ away from the coast of Bay of Bengal.

\section{Morphological Characters of Selected Blackgram Genotypes}

\section{Estimation of Leaf Thickness (mm)}

A total of 16 genotypes indicating all categories of reactions were selected from the genotypes evaluated during kharif 201516,(data not shown) and were sown in three replications of $5 \mathrm{~m}$ each at Agricultural college, Bapatla, Department of plant pathology during rabi 2015-16. Three plants were selected at random from each genotype at 45 DAS.

Three leaves from each plant were selected randomly from each plant to measure leaf thickness by using Venier callipers (Perez et al., 2013). Same genotypes and similar sampling method have been used for estimation of stomatal frequency, trichome density, and biochemical analysis.

\section{Estimation of Stomatal Frequency (number of stomata/ $\mathrm{mm}^{2}$ )}

Healthy trifoliate leaf of from 45 days old have been collected and then were smeared with synthetic gum. It's gum is being allowed to dry, flakes have been peeled and mounted on microscope glass slide. Number of stomata per $\mathrm{mm}^{2}$ was counted using ocular micrometer with $40 \mathrm{X}$ objective lens (Varadarajan and Wilson, 1973).

\section{Estimation of Trichome Density $(5 \mathrm{~mm}$ dia leaf disc)}

Circular leaf discs with such a diameter $5 \mathrm{~mm}$ have been made from punching machine soaked in saffron dye for 5-10 min which were used to validate the number of hairs using stereo zoom microscope as outlined by Tagger and Gill (2012).

\section{Biochemical Analysis}

\section{Glassware and sterilization}

The glassware used in this study viz., Borosil, Petri plates, conical flasks, test tubes, pipettes, measuring cylinders, beakers, micropipettes and microtips have been used in this study. Glassware was washed first with detergent powder and then rinsed under tap water. Subsequently they was kept overnight in cleaning solution prepared by mixing $75 \mathrm{~g}$ of potassium dichromate, $500 \mathrm{ml}$ of concentrated sulphuric acid and $1000 \mathrm{ml}$ of distilled water and rinsed with tap water followed by distilled water and analytical or reagent grade chemicals were used in the latter study.

\section{Estimation of Total phenols}

Total phenols were estimated by FolinCiocalteau Reagent method (Malick and Singh, 1980). 


\section{Estimation of total sugars}

Total sugars were estimated following Anthrone method (Hodge and Hofreiter, 1962).

\section{Estimation of reducing sugars}

Reducing sugars estimation was carried out by Dinitrosalicylic acid method (Miller, 1959).

\section{Estimation of non-reducing sugars}

The non-reducing sugar quantity was determined by deducting the reducing sugar content from that of the total soluble sugars

\section{Statistical Analysis}

The data obtained from all the experiments were statistically analyzed following the standard procedures (Gomez and Gomez, 1984).

Morphological characters was measured by concerned apparatus as mentioned above, as well as biochemical analysis measured by spectrophotometer and estimated according their formulas.

\section{Results and Discussion}

Among morphological characters, features of stomata, cuticle and trichome morphology can impact disease resistance (Niks and Rubiales, 2002).

\section{Morphological and Vegetative Characters in Selected Blackgram Genotypes}

\section{Leaf thickness $(\mu \mathrm{m})$}

Significantly highest leaf thickness was observed in highly resistant genotypes KUP$34(201.4 \mu \mathrm{m}), \mathrm{KUP}-40(191.3 \mu \mathrm{m})$ and four moderately resistant genotypes KUP-12 $(176.2 \mu \mathrm{m})$, KUP-6 $(173.6 \mu \mathrm{m})$, KUP-11 $(171.7 \mu \mathrm{m})$, KUP-31 $(167.3 \mu \mathrm{m})$ which were on a par.

Two susceptible genotypes KUP-39 (134.8 $\mu \mathrm{m}), \quad$ KUP-25 $(135.7 \mu \mathrm{m})$ and four moderately susceptible genotypes viz., KUP$27(138.1 \mu \mathrm{m})$, KUP-30 (139.9 $\mu \mathrm{m})$, KUP-4 $(143.1 \mu \mathrm{m})$ and KUP-5 $(141.8 \mu \mathrm{m})$ showed significantly less leaf thickness compared to highly resistant category and were on par. Highly susceptible genotype LBG-623 (107.3 $\mu \mathrm{m})$ which showed lowest leaf thickness which was on par with one susceptible genotype KUP-37 $(118.6 \mu \mathrm{m})$ (Table.1).

High degree of resistance and moderate resistance to powdery mildew in the blackgram genotypes can be attributed to higher leaf thickness. Cuticle thickness in phlox found to be more in resistant genotype Texas $4 \mathrm{n}$ than susceptible genotype Oklahoma as reported by Andrew et al., (1982). Leaf and cuticular or epidermal thickness have also been associated with powdery mildew resistance (Commenil et al., 1997).

\section{Stomatal frequency (per $\mathrm{mm}^{2}$ )}

Significantly lowest stomatal frequency was observed in highly resistant genotypes KUP$34\left(88.64 / \mathrm{mm}^{2}\right)$, KUP-40 $\left(99.24 / \mathrm{mm}^{2}\right)$ and were on a par with moderately resistant genotypes KUP-12 $\left(104.55 / \mathrm{mm}^{2}\right)$, KUP-6 $\left(107.58 / \mathrm{mm}^{2}\right)$, KUP-11 $\left(106.82 / \mathrm{mm}^{2}\right)$, KUP$31 \quad\left(109.09 / \mathrm{mm}^{2}\right)$. Highly susceptible genotype LBG-623 $\left(193.94 / \mathrm{mm}^{2}\right)$ and one susceptible genotype KUP-37 $\left(184.85 / \mathrm{mm}^{2}\right)$ were found to have highest stomatal frequency and were on a par (Fig. 2 and Plate 1). Stomatal frequency was observed to be an important character in determining the resistance in the studied genotypes. Dhanumjayrao et al., (2006) observed high 
variation in stomatal density in grape genotypes against powdery mildew.

\section{Trichome density (5mm diameter disc)}

Significantly higher trichome density was observed in highly resistant genotypes KUP34 (62.33), KUP-40 (59.11) and were on a par with each other. Four moderately resistant genotypes viz., KUP-12 (42.56), KUP-6 (41.11), KUP-11 (36.00), KUP-31 (38.78) and two moderately susceptible genotypes KUP-4 (36.56), KUP-15 (39.44) showed on a par trichome density with that of resistant genotypes. Rest of the moderately susceptible genotypes were significantly low trichome density and were on a par. The highly susceptible genotype LBG-623 (19.33) was found to possess significantly lowest trichome density and was on par with one susceptible genotype KUP-37 (25.0) (Fig. 3 and Plate 2).

In highly resistant and moderately resistant genotypes, the trichome density was found to be significantly highest which implies that trichome density can a morphological character contributing for the resistance of blackgram genotypes to powdery mildew.

Trichomes play an important role by inhibiting penetration of the pathogen into the host plant by keeping the pathogen away from the infection courts (Horsfall and Diamond, 1960). Similarly, Martin and Glover (2007) found that trichomes can act as physical barriers to infection. High frequency of trichomes can also prevent mycelial penetration and infection of other biotrophic fungi (Shalik, 1985). From the work of Kortekamp and Zyprian (1999), it appears that increased number of hydrophobic pubescences may repel water from leaf surfaces thus preventing successful penetration. Alternatively, a high trichome number may simply reduce the frequency of germ tube contact points that can lead penetration (Niks and Rubiales, 2002). The results strongly suggested that morphological characters showed resistance to powdery mildew has existed among genotypes.

\section{Studies on Biochemical Variability in Selected Black gram Genotypes}

\section{Total Phenols content (mg/100 mg)}

Significantly difference in phenol content was observed in between two highly resistant genotypes KUP-34 (0.912 mg/100 mg) and KUP-40 (0.861 mg/100 mg) followed by a moderately resistant genotype KUP-12 (0.678 $\mathrm{mg} / 100 \mathrm{mg})$. Susceptible and highly susceptible genotypes showed lowest phenol content and there are on a par. Overall differential phenol contents was observed among highly resistant and moderately resistant genotypes and moderately susceptible and susceptible genotypes (Fig 4).

Total phenol content has a role to play in resistance mechanism. Concentration of phenolic compounds was usually higher in resistant genotypes than in susceptible genotypes of different crop plants (Arora and wagle, 1985, Saini et al., 1988). Parashar and Sindhan (1986) noted higher content of total phenols in stem and leaf of powdery mildew resistant varieties of pea than susceptible. Kalia and Sharma (1988) found higher levels of phenolics and phenol oxidising enzymes in resistant cultivars of pea ( $\mathrm{P} 185$ and $\mathrm{P}$ 6583) than susceptible, the correlation between the biochemical parameters and disease index were also high. Hattappa et al., (2003) noticed that the biochemical changes in mulberry (Morus alba) leaves infected with Phyllactinia corylea causing powdery mildew the total chlorophyll, reducing sugar and protein content of mulberry leaves decreased with increased infection by the fungus. Helal et al., (1978) reported that the resistance to $E$. cichoracearum in the cucumber variety 
Poinsettia was due to a high concentration of phenols which hindered infection and a low concentration of sugars prevented establishment of the pathogen in the host tissues.

\section{Total soluble sugars}

\section{Total Sugars content (mg/100 mg)}

Significantly lowest sugar content was observed in highly resistant genotypes KUP34 (4.48 mg/100 mg) KUP-40 (4.62 mg/100 $\mathrm{mg}$ ) and were on a par in their total sugar content with moderately resistant genotypes viz., KUP-12 (4.63 mg/100 mg), KUP-6 (4.65 $\mathrm{mg} / 100 \mathrm{mg})$, KUP-11 (4.66 mg/100 mg) and KUP-31 (4.74 mg/100 mg). Highest total sugar content was observed in highly susceptible genotype LBG-623 (7.39 mg/100 mg) (Fig.5). Resistance of genotypes was inverse to the total sugar content.

\section{Reducing sugars content (mg/100 mg)}

Highly resistant genotypes KUP-34 (2.39 $\mathrm{mg} / 100 \mathrm{mg})$ and KUP-40 (2.36 mg/100 mg) did not significantly differ in their reducing sugar content and were on par with moderately resistant genotypes, KUP -12 (2.70 mg/100 mg), KUP -6 (2.67 mg/100 mg), KUP -11 (2.67 mg/100 mg) and KUP-31 $(2.82 \mathrm{mg} / 100 \mathrm{mg})$ in their reducing sugar contents. Moderately susceptible genotypes viz., KUP-15 (2.89 mg/100 mg) and KUP -18 (2.71 mg/100 mg) observed to have reducing sugar content on par with highly resistant and moderately resistant genotypes and one highly susceptible genotype LBG-623 (4.10 mg/100 $\mathrm{mg}$ ) were on par in their reducing sugars content. Highly resistant genotypes showed lowest reducing sugar contents (Fig.6)

\section{Non-reducing sugars (mg/100 mg)}

Highly resistant genotypes KUP-34 (1.96 $\mathrm{mg} / 100 \mathrm{mg}$ ), KUP-40 (2.26 mg/100 mg) observed to have lowest non-reducing sugars, they did not differ significantly in their nonreducing sugar content and were on par with moderately resistant genotypes viz., KUP-12 (1.94 mg/100 mg), KUP-6 (1.64 mg/100 mg), KUP-11 (2.00mg/100 mg) and KUP-31 (1.92 $\mathrm{mg} / 100 \mathrm{mg}$ ) in non-reducing sugar content and with highly susceptible genotypes LBG$623(3.39 \mathrm{mg} / 100 \mathrm{mg})$ for the non-reducing sugar content (Fig.7).

Non reducing sugar content in the genotypes showed an inverse relation with resistance to powdery mildew. Early decades, Muhammad and Ali (2014) found that incidence of powdery mildew in pea induces changes in reducing sugars, non-reducing sugars, total sugars powdery mildew resistant and susceptible peas genotypes. Dakshayani et al., (2005) reported that the susceptible genotypes Chinamung, Pusa Baisakhi and TM-98-50 recorded higher levels of sugars compared to the TARM-18. Parashar and Sindhan (1986) reported that powdery mildew resistant pea varieties (P185 and P388) had higher contents of total phenols in stem and leaf and low concentration of total sugars and reducing sugars, than susceptible varieties. Gawande et al., (2002) carried out a biochemical study on reducing, non-reducing and total sugars and found that resistant genotypes had lower total sugars content before and after infection. Guleria et al., (1997) reported the postinfection of powdery mildew decrease the reducing sugar content in the leaves of both resistant (DPP68 and JP71) and susceptible cultivars (Bonneville and Lincoln) in pea.

\section{Stomatal Frequency and Trichome Density}

Braun (1987b) revealed that some lines in the mildew-susceptible germplasm of mulberry of which RFS-135, Mother graft, Shrim-5 and Mizuzawa) have a smaller stomatal density, the number of stomata per unit area of leaf surface and stomatal index were positively 
correlated with powdery mildew resistance. Eighty per cent of the resistant germplasm were characterized by high trichome densities and a high stomatal density and stomatal index. There are some significant genotypic effects of stomatal frequency on penetration by powdery mildew pathogens (Lima et al., 2010). Chattopadhyay et al., (2011) evaluated 30 lines of mulberry with contrasting susceptibilities to powdery mildew (15 resistant and 15 susceptible), susceptible genotypes showed significant more stomatal index, stomatal area and less trichome density. Whereas, resistant group was distinguished by $17.4 \%$ lower stomatal density, $12.5 \%$ smaller stomatal index per unit leaf area, $20.0 \%$ greater trichome density and $18.0 \%$ higher stomatal area compared with the susceptible group. Trichome density was negatively correlated with disease severity index and with the accumulative area under disease progression curves (AUPDC). Georgiev et al., (2013) found positive relation between the degree of pubescence and resistance to powdery mildew under natural conditions.

Table.1 Biochemical characters in selected blackgram genotypes

\begin{tabular}{|c|c|c|c|c|c|c|}
\hline Sl.No. & Genotypes & $\begin{array}{l}\text { Disease } \\
\text { reaction }\end{array}$ & $\begin{array}{c}\text { Total phenols } \\
\text { (mg/100mg) }\end{array}$ & $\begin{array}{l}\text { Total sugars } \\
\text { (mg/100mg) }\end{array}$ & $\begin{array}{l}\text { Reducing } \\
\text { sugars } \\
\text { (mg/100mg) }\end{array}$ & $\begin{array}{c}\text { Non-reducing } \\
\text { sugars }(\mathbf{m g} / \mathbf{1 0 0 m g})\end{array}$ \\
\hline 1 & KUP-34 & HR & $* 0.912^{\mathrm{a}}$ & $4.48^{\mathrm{e}}$ & $2.39^{\mathrm{c}}$ & $1.96^{\mathrm{c}}$ \\
\hline 2 & KUP-40 & HR & $0.861^{b}$ & $4.62^{\mathrm{e}}$ & $2.36^{\mathrm{c}}$ & $2.26^{\mathrm{bc}}$ \\
\hline 3 & KUP-12 & MR & $0.678^{c}$ & $4.63^{\mathrm{e}}$ & $2.70^{\mathrm{bc}}$ & $1.94^{c}$ \\
\hline 4 & KUP-6 & MR & $0.617^{\mathrm{d} .}$ & $4.65^{\mathrm{e}}$ & $2.67^{b c}$ & $1.64^{\mathrm{c}}$ \\
\hline 5 & KUP-11 & MR & $0.581^{\mathrm{d}}$ & $4.66^{\mathrm{e}}$ & $2.67^{\mathrm{bc}}$ & $2.00^{c}$ \\
\hline 6 & KUP-31 & MR & $0.487^{\mathrm{e}}$ & $4.74^{\mathrm{e}}$ & $2.82^{b c}$ & $1.92^{\mathrm{c}}$ \\
\hline 7 & KUP-15 & MS & $0.475^{\mathrm{e}}$ & $5.97^{\mathrm{bcd}}$ & $2.89^{b c}$ & $3.08^{\mathrm{a}}$ \\
\hline 8 & KUP-18 & MS & $0.448^{\text {ef }}$ & $5.90^{\mathrm{bcd}}$ & $2.71^{b c}$ & $3.19^{\mathrm{a}}$ \\
\hline 9 & KUP-4 & MS & $0.422^{f}$ & $5.83^{\mathrm{d}}$ & $3.01^{\mathrm{b}}$ & $3.16^{\mathrm{a}}$ \\
\hline 10 & KUP-5 & MS & $0.381^{\mathrm{g}}$ & $5.84^{\mathrm{d}}$ & $2.82^{b c}$ & $3.02^{\mathrm{a}}$ \\
\hline 11 & KUP-30 & MS & $0.365^{\text {gh }}$ & $5.96^{\text {bcd }}$ & $2.89^{b c}$ & $3.07^{\mathrm{a}}$ \\
\hline 12 & KUP-27 & MS & $0.358^{\text {ghi }}$ & $5.97^{\mathrm{bcd}}$ & $2.96^{\mathrm{bc}}$ & $3.02^{\mathrm{a}}$ \\
\hline 13 & KUP-25 & $\mathbf{S}$ & $0.328^{\text {hij }}$ & $6.93^{\mathrm{abc}}$ & $3.87^{\mathrm{a}}$ & $3.05^{\mathrm{a}}$ \\
\hline 14 & KUP-39 & $\mathbf{S}$ & $0.317^{\mathrm{ij}}$ & $7.01^{\mathrm{ab}}$ & $4.00^{\mathrm{a}}$ & $2.91^{\mathrm{ab}}$ \\
\hline 15 & KUP-37 & $\mathbf{S}$ & $0.308^{j}$ & $6.91^{\mathrm{abcd}}$ & $4.05^{\mathrm{a}}$ & $2.86^{\mathrm{ab}}$ \\
\hline 16 & LBG 623 & HS & $0.299^{j}$ & $7.39^{\mathrm{a}}$ & $4.10^{\mathrm{a}}$ & $3.39^{\mathrm{a}}$ \\
\hline
\end{tabular}

Fig.1 Variation of leaf thickness $(\mu \mathrm{m})$ in selected blackgram genotypes

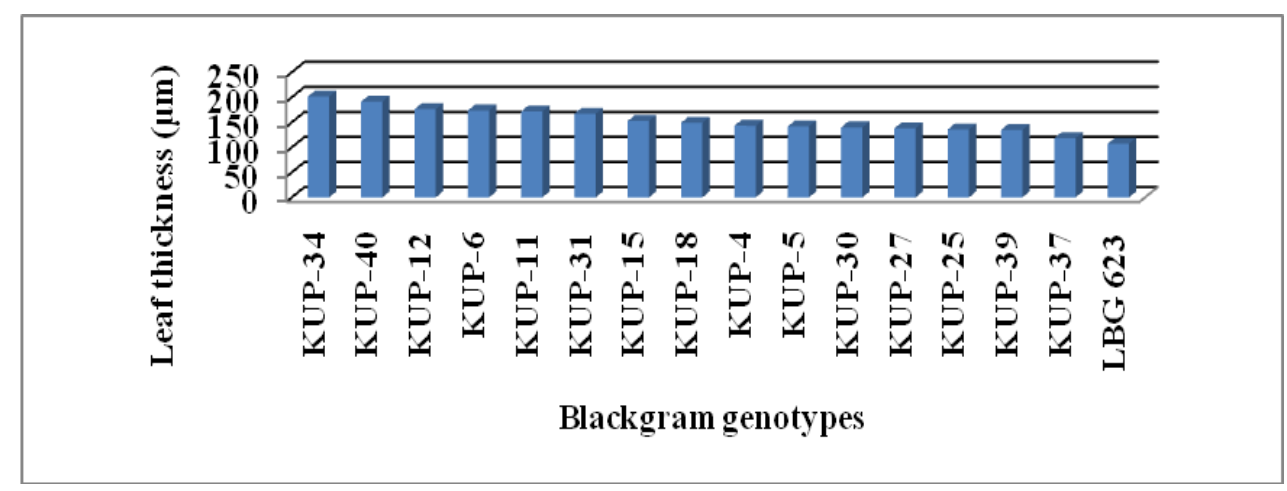


Fig.2. Variation in stomatal frequency (no of stomata $\mathrm{mm}^{2}$ ) in selected blackgram genotypes

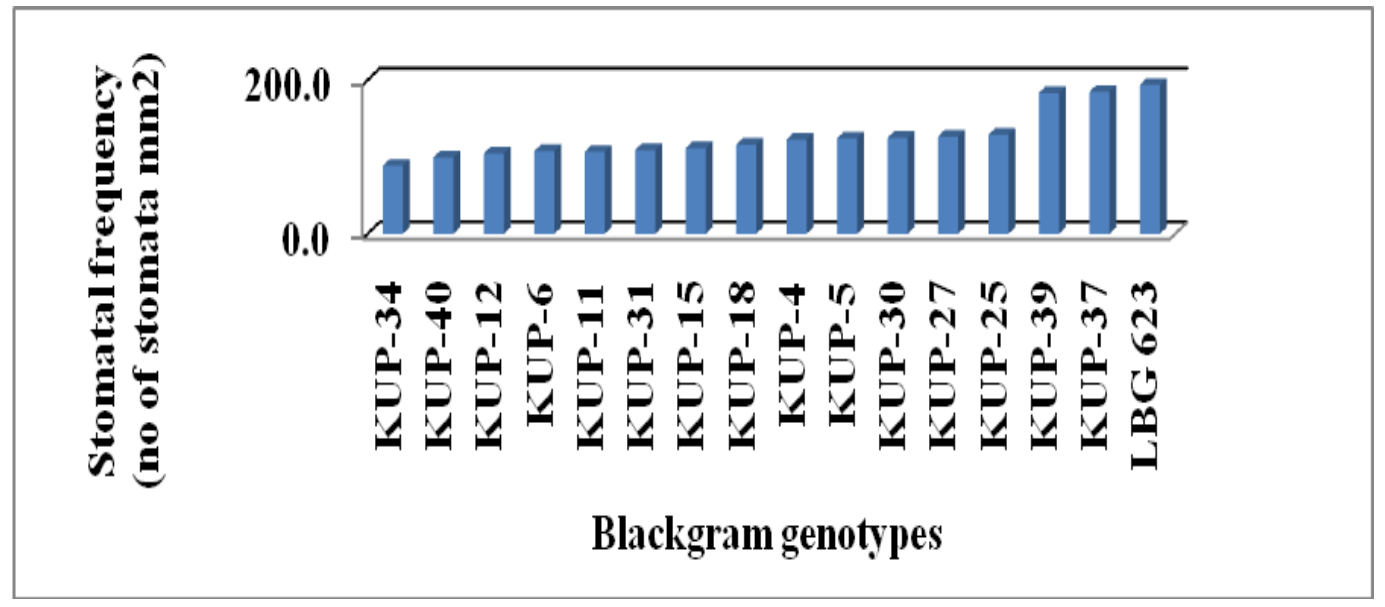

Fig.3 Variation of trichome density ( $5 \mathrm{~mm}$ dia leaf disc) in selected black gram genotypes

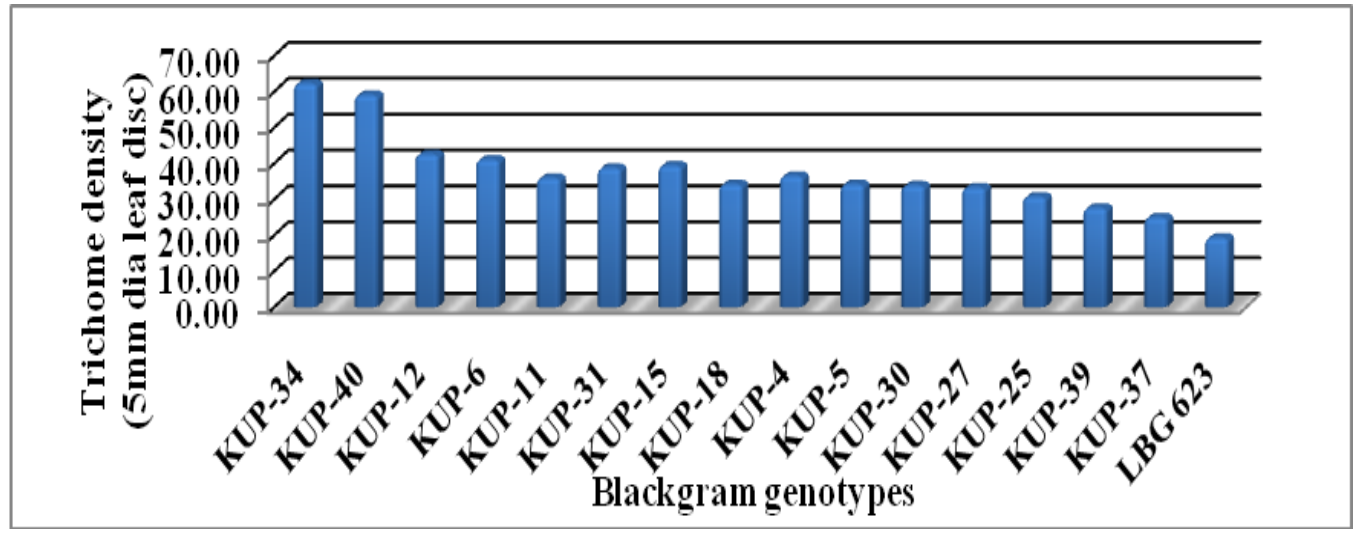

Fig.4 Variation in total phenols $(\mathrm{mg} / 100 \mathrm{mg})$ on selected blackgram genotypes

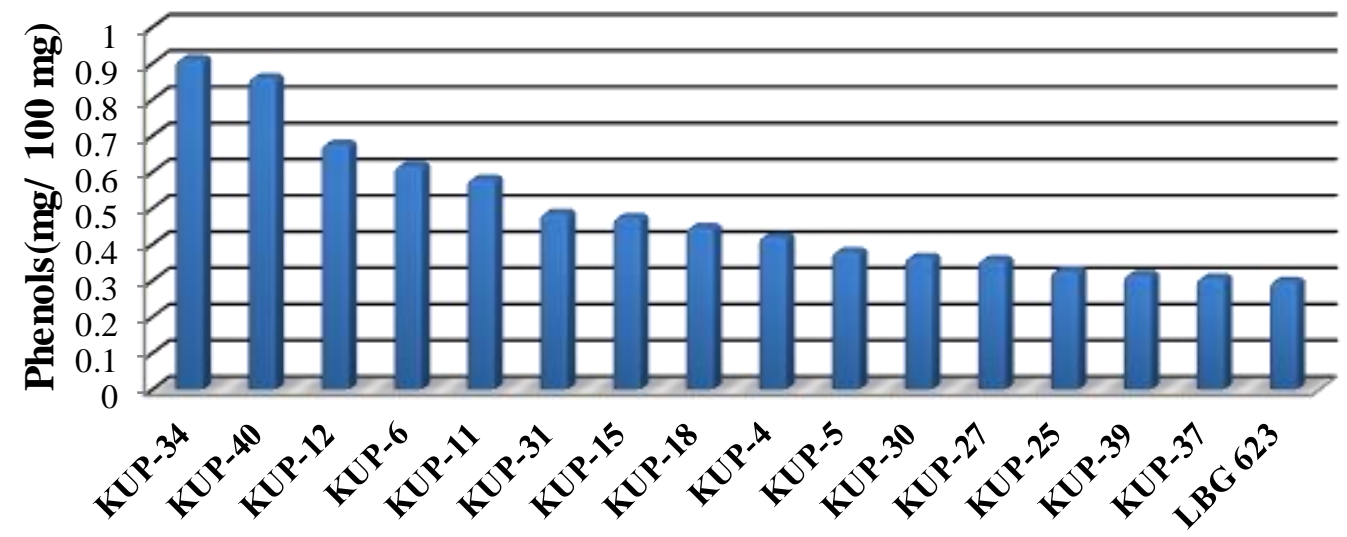

Blackgram genotypes 
Fig.5 Variation in total sugars $(\mathrm{mg} / 100 \mathrm{mg})$ on selected blackgram genotype

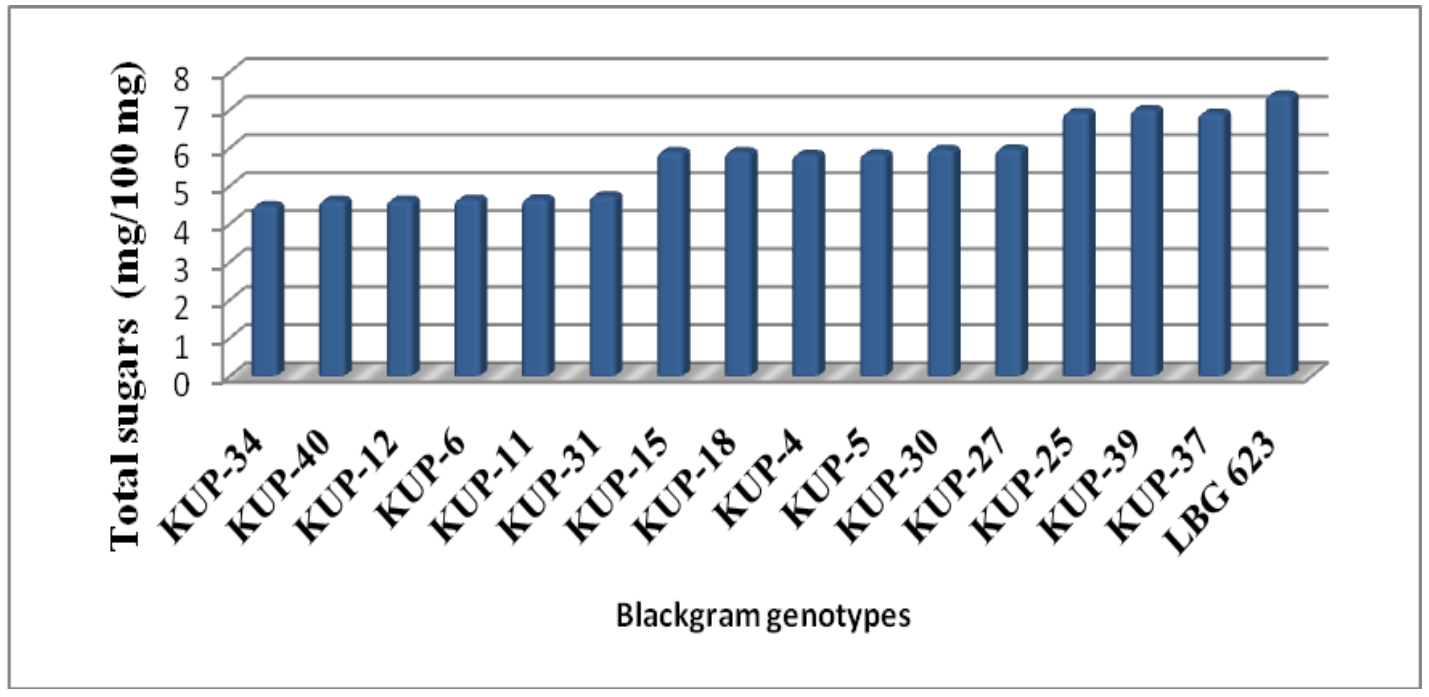

Fig.6 Variation of reducing sugars $(\mathrm{mg} / 100 \mathrm{mg})$ in selected blackgram genotypes

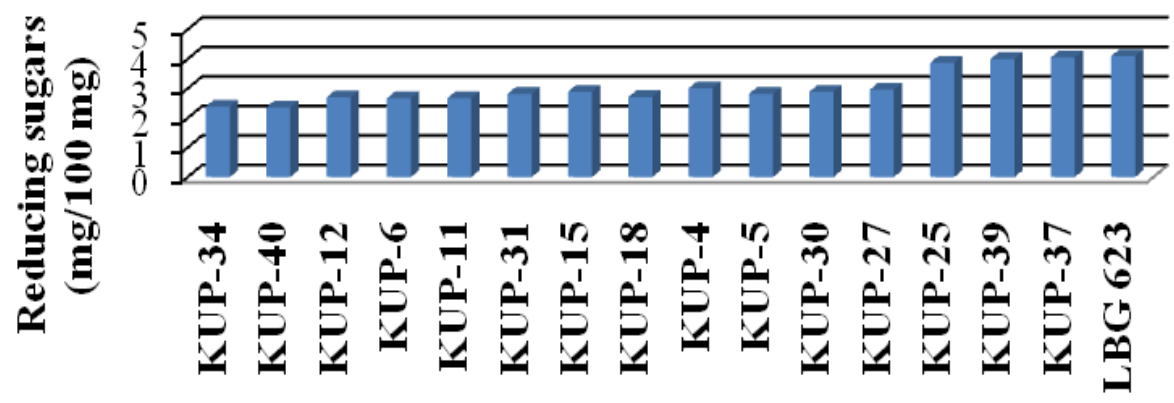

\section{Blackgram genotypes}

Fig.7 Variation of non-reducing sugars $(\mathrm{mg} / 100 \mathrm{mg})$ in selected blackgram genotypes

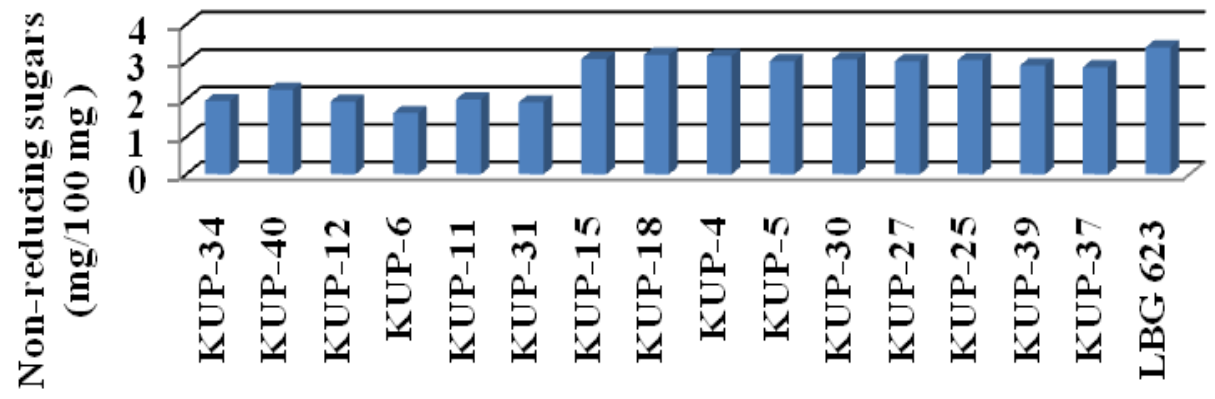

Blackgram genotypes 
Plate.1 Variation in stomatal frequency in powdery mildew disease resistant (KUP-34) and susceptible (LBG-623) black gram genotypes

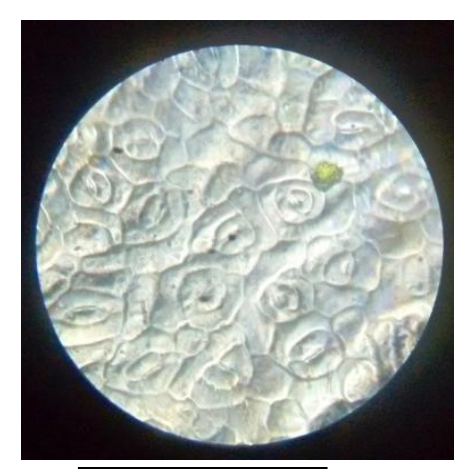

KUP-34

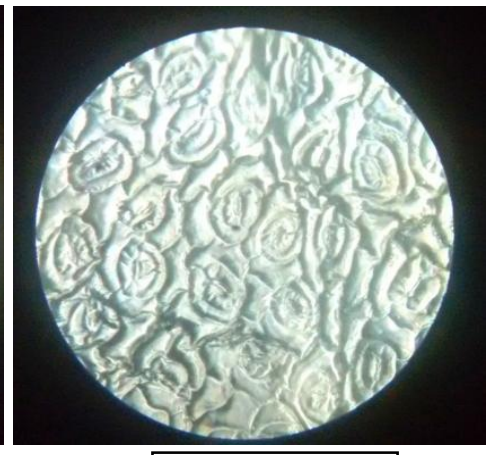

LBG-623

Plate.2 Variation in trichome density in powdery mildew disease resistant (KUP-34) and susceptible (LBG-623) black gram genotypes

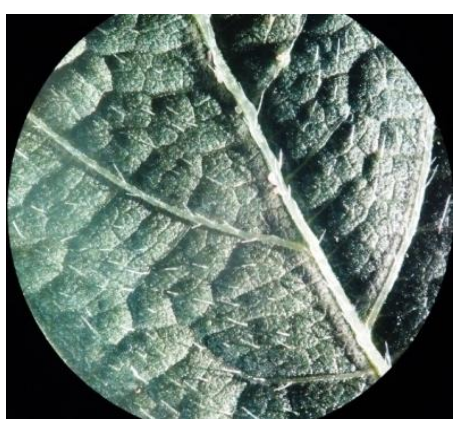

KUP-34

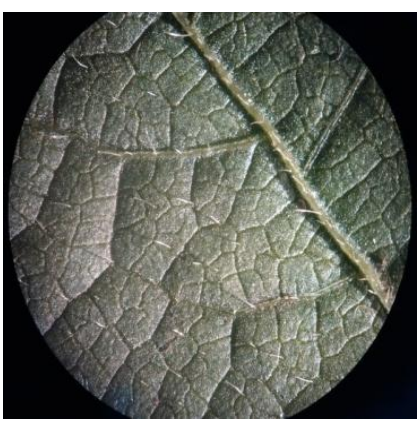

LBG-623

\section{Biochemical Characters for Disease Resistance}

Involvement of phenolic compounds in many aspects of plant parasite relationship other than plant protection has been reported by Friend in 1979. The role of phenolics in the resistance mechanisms in plants has been reviewed by several workers (Allen, 1959; Agrios, 2005). Concentration of phenolic compounds was usually higher in resistant genotypes than in susceptible genotypes of different crop plants (Arora and Wagle, 1985 and Saini et al., 1988).Mandahar and Garg (1975) observed that okra leaves infected with powdery mildew (E. cichoracearum) had higher reducing sugars content than healthy leaves. Helal et al., (1978) reported that the resistance to $E$. cichoracearum in the cucumber variety Poinsettia was due to a high concentration of phenols which hindered infection and a low concentration of sugars prevented establishment of the pathogen in the host tissues. Guleria et al., (1997) reported the post-infection decrease the reducing sugar content in the leaves of both resistant (DPP68 and JP71) and susceptible cultivars (Bonneville and Lincoln) of pea against powdery mildew. Sridhan and Parashar (1984) found higher content of total phenols, O-dihydric phenols, $\mathrm{P}, \mathrm{K}, \mathrm{Zn}$, and $\mathrm{Cu}$ but lower of $\mathrm{N}, \mathrm{Mn}$, and $\mathrm{Fe}$ in the foliage of resistant and moderately resistant varieties of pea compared to susceptible. Parashar and 
Sindhan (1986) noted higher content of total phenols and Orthodihydro-phenols and lower of total sugars and reducing sugars in stem and leaf of powdery mildew of resistant varieties of pea than susceptible. Kalia and Sharma (1988) found higher levels of phenolics and phenol oxidising enzymes in resistant cultivars of pea (P 185 and $\mathrm{P}$ 6583) than susceptible cultivars, the correlation between the biochemical parameters and disease index were also high. Sharma et al., (1996) found higher total phenol content in powdery mildew resistant varieties of pea viz., JP 179, JM 5, PMR 3 AND PMR 4.

Gawande et al., (2002) carried out biochemical study on reducing, non-reducing and total sugars and total phenols before and after powdery mildew infection in seven mungbean genotypes found that resistant genotypes had higher total phenols before and after infection. The total phenols were positively correlated with resistance. Whereas, sugars were negatively associated with disease resistance. Dakshayani et al., (2005) reported that the susceptible genotypes Chinamung, Pusa Baisakhi and TM-98-50 recorded higher levels of sugars compared to the TARM-18. Muhammad and Ali (2014) found that incidence of powdery mildew in pea induces changes in reducing sugars, nonreducing sugars, total sugars powdery mildew resistant and susceptibility of peas genotypes.

In conclusion the 15 blackgram genotypes, significantly highest leaf thickness was observed in highly resistant genotypes KUP$34(201.4 \mu \mathrm{m})$, KUP-40 (191.3 $\mu \mathrm{m})$. Highly susceptible genotype LBG-623 (107.3 $\mu \mathrm{m})$ which showed lowest leaf thickness which was on par with one susceptible genotype KUP-37 (118.6 $\mu \mathrm{m})$. Significantly lowest stomatal frequency was observed in highly resistant genotypes KUP-34 $\left(88.64 / \mathrm{mm}^{2}\right)$,

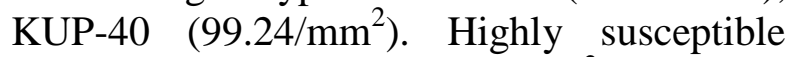
genotype LBG-623 $\left(193.94 / \mathrm{mm}^{2}\right)$ and one susceptible genotype KUP-37 (184.85/mm²) were found to have highest stomatal frequency. Significantly higher trichome density was observed in highly resistant genotypes KUP-34 (62.33), KUP-40 (59.11) and were on a par with each other. The highly susceptible genotype LBG-623 (19.33) was found to possess significantly lowest trichome density. Significantly higher phenol content was observed in highly resistant genotypes KUP-34 (0.912 mg/100 mg) and KUP-40 $(0.861 \mathrm{mg} / 100 \mathrm{mg})$ and one moderately resistant genotype KUP-12 (0.678 mg/100 $\mathrm{mg})$. Highly susceptible genotype LBG-623 recorded the lowest total phenol content (0.299 mg/100 mg).

Significantly lowest sugar content was observed in highly resistant genotypes KUP34 (4.48 mg/100 mg) KUP-40 (4.62 mg/100 $\mathrm{mg}$ ) and were on a par. Highest total sugar content was observed in highly susceptible genotype LBG-623 (7.39 mg/100 mg). Highly resistant genotypes KUP-34 (2.39 mg/100 $\mathrm{mg})$ and KUP-40 (2.36 mg/100 mg) showed lowest reducing sugars and there on a par. Highly resistant genotypes KUP-34 (1.96 $\mathrm{mg} / 100 \mathrm{mg})$, KUP-40 (2.26 mg/100 mg) showed observed to have lowest non reducing sugars, they did not differ significantly in their non-reducing sugar content.

\section{Acknowledgement}

Authors are grateful to Head, Department of Plant Pathology, Regional Agricultural Research Station, Lam, Guntur District, Agricultural College Farm for providing the necessary facilities to undertake this work.

\section{References}

Agrios, G.N. 2005. Powdery mildews. Plant Pathology, $5^{\text {th }}$ ed. San Diego USA. Elsevier Academic Press. 346

Allen, P.J. 1959. Physiology and biochemistry 
of defense. In Horsfall, J.G. \& Dimond, A.E. Plant Pathology. 435-469.

Arora,Y.K and Wagle, D.S. 1985. Interrelationship between peroxidase, polyphenol oxidase activities and phenolic content of wheat for resistance to loose smut. Biochemie und Physiologieder Pflanzen. 180: 75-80.

Braun, U. 1987b. A monograph of the Erysiphales (powdery mildews). Beihefte zur Nova Hedwigia. 89: 700.

Chattopadhyay, S., Ali, K.A., Gandhi, D., Nirvan, K., Ramesh, K., Aggarwal., Tapas, K., Bandopadhyay., Sarkar, A and Bajpai, A.K. 2011. Association of leaf micro-morphological characters with powdery mildew resistance in field-grown mulberry (Morus spp.) germplasm. $\quad A O B \quad$ Plants. http://www.ncbi.nlm. nih.gov/pmc/articles.

Commenil, P., Brunet, L and Audran, J.C. 1997. The development of the grape berry cuticle in relation to susceptibility to bunch rot disease. Journal of Experimental Botany. 48: 1599-1607.

Dakshayani, R., Mummigatti, U.V., Kulkarni, S and Kumar, R. L. 2005. Screening of green gram genotypes for powdery mildew using biochemical parameters. Karnataka Journal of Agricultural Sciences. 18: 500-502.

Department of Agriculture and Cooperation, Government of A.P. 2018. Area and production of agricultural crops in Andhra Pradesh. www.agri.ap.nic.in.

Dhanumjayarao, K., Jindal, P.C., Singh, R., Srivastava and Sharma, R.C. 2006. Biochemical variability studies for disease resistance in grape germplasm against powdery mildew with varietal characters. Indian Journal of Agricultural Research. 40: 212-214.

Duffus, C.M and Slaughter, 1980. Seed and their uses. Wiley and sons Chichester. New York. USA. 60-64.
Friend, J. 1979. Phenolic substances and plant diseases. In : Biochemistry of plant phenolics (Swin. T., Harbone, B.J. and Sumere, F.V (Eds). 557-588.

Gawande, V.L., Patil, J.V., Naik, R.M and Kale, A.A. 2002. Plant biochemical defense against powdery mildew (Erysiphe polygoni D C) disease in mungbean (Vigna radiate (L.) Wilczek). Journal of Plant Biology. 29: 337-341.

Georgiev, K and Galina, K and Naydenova. 2013. Physiological function of nonglandular trichomes in red clover (Trifolium pretense). Journal of Agricultural Sciences. 58: 217-222.

Guleria, P.B., Bajaj, K.L., Guleria, S and Paul, B. 1997. Plant Disease Research. 12: $185-188$.

Hattappa, S., Chattopadhyay, S and Dutta, S.K. 2003. Some Biochemical Changes in the Leaves of Mulberry (Morus alba L.). Infected by Powdery Mildew (Phyllactinia corylea (Peis, Karst). Environment and Ecology. 21: 47-49.

Helal, R.M., Zaki, M.S and Fadl, F.A. 1978. Physiological studies on the nature of resistance to powdery mildew in cucumber. Research Bulletin. Ain Shams. University, Cairo.12.

Hodge, J.E and Hofreiter, B.T. 1962. In: Methods in Carbohydrate Chemistry. (eds.) Whistler, R.L. and Be Miller, J.N., Academic Press, New York. 420.

Horsefall, J.G and Diamond, A.E. 1960. Plant pathology-An advanced treatise. 123

Kalia, P and Sharma, S.K. 1988. Biochemical genetics of powdery mildew resistance in pea. Theoretical and Applied Genetics. 76: 795-799.

Kortekamp, A and Zyprian, E. 1999. Leaf hairs has basic protective barrier against downy mildew of grape. Journal of Phytopathology.147: 453-459.

Kumar, M.V. 1999. Studies on powdery mildew (Erysiphe polygoni DC) on 
blackgram - rice fallows of Guntur district. Msc. Thesis Acharya.N.G. Ranga Agricultural University, Bapatla, India.

Lima, P., Lopes, C.A and CafeFilho, A.C. 2010. Stomatal patterns of capsicum genotypes resistant or susceptible to Oidlopsis haplophylli. Summa Phytopathologia. 36: 25-29.

Miller, G.L. 1959. Use of dinitrosalicylic acid reagent for determination of reducing sugar. Analytical Chemistry. 31: 426428.

Muhammad, A.A and Ali, K.A. 2014. Powdery mildew induced physiological and biochemical changes in pea. Pakisthan Journal of Agricultural Sciences. 51: 893-899.

Niks, R.E and Rubiales, D. 2002. Potentially durable resistance mechanisms in plants to specialized fungal pathogens. Euphytica.124: 216-216.

Parashar, R.D and Sindhan, G.S. 1986. Biochemical changes in varieties resistant and susceptible to powdery mildew disease. Progressive Horticulture. 18: 135-137.

Pérez-Harguindeguy, N., PérezHarguindeguy, A.Y.S., Díaz, A.E., Garnier, B.S., Lavorel, C.H., Poorter, D.P., Jaureguiberry, A.M.S., Bret-Harte, E.W.K., Cornwell, F.J.M., Craine, G.D.E., Gurvich, A.C., Urcelay, A.E.J., Veneklaas, H.P.B., Reich, I.L., Poorter,
J.I.J., Wright, K.P., Ray, L.L., Enrico, A.J.G and Pausas, M.A.C. 2013. New handbook for standardised measurement of plant functional traits worldwide F. 2013. Journal of Botany. 61: 167-234.

Rachie, K.O and Roberts, L.M. 1974. Grain legumes of low land tropics. Advances in Agronomy. 26: 1-132.

Saini, R.S., Arora, Y.K, Chawla, H.K.L and Wagle, D.S. 1988. Total phenols and sugar content in wheat cultivars resistant and susceptible to Ustilago nuda (Jens) Rostrup. Biochemie und Physiologie der Pflanzen. 183: 89-93.

Shaik, M. 1985. Race non-specific resistance in bean cultivars to races of Uromyces appendiculatus var. appendiculatus and its correlation with leaf epidermal characters. Phytopathology.75: 478481.

Sirdhan, G.S and Parashar, R.D. 1984. A comparative study of pea varieties resistant and susceptible to powdery mildew disease. Progressive Horticulture. 16: 137-139.

Taggar, G.K and Gill, R.S. 2012. Preference of Whitefly, Bemisia tabaci, towards blackgram genotypes: Role of morphological leaf characteristics. Phytoparasitica. 40: 461-474.

Varadarajan, F and Wilson, K.J. 1973. A technique to spore germination studies on plant leaves. Current Science. 42: 70.

\section{How to cite this article:}

Tulasi Korra and Manoj Kumar, V. 2020. Erysiphe polygoni Induced Morpho-physiological and Biochemical Changes in Blackgram (Vigna mungo). Int.J.Curr.Microbiol.App.Sci. 9(07): 1877-1888. doi: https://doi.org/10.20546/ijcmas.2020.907.215 